\title{
A country-wide comparison of cost recovery and financing systems of blood and blood products
}

Nasim Divkolaye, ${ }^{1,2}$ Fariba Seighali, ${ }^{3}$ Ali Akbar Pourfathollah ${ }^{4}$ and Cees Th. Smit Sibinga ${ }^{5}$

${ }^{1}$ International Affairs Department, Iranian Blood Transfusion Organization, Tehran, Islamic republic of Iran. ${ }^{2}$ Global Health Policy Degree Candidate, Faculty of Public Health and Policy, London School of Hygiene and Tropical Medicine, London, United Kingdom. ${ }^{3 B}$ Blood Transfusion Research Center, High Institute for Research \& Education on Transfusion Medicine, Tehran, Islamic Republic of Iran. ${ }^{4}$ Department of Immunology, Faculty of Medical Sciences, Tarbiat Modares University, Tehran, Islamic Republic of Iran. ${ }^{5} \mathrm{IQM}$ Consulting for International Development of Quality Management in Transfusion Medicine, University of Groningen, Netherlands. (Correspondence to: Fariba Seighali: fseighali@yahoo.com).

\begin{abstract}
Background: As blood is a scarce and expensive resource, irrational blood usage places huge burden on health expenditures. In response to this challenge, governments and health care providers are developing different strategies to optimize blood utilization. Among these strategies is trying to raise the public awareness on the actual costs of the blood production and changing the cost recovery systems of blood and blood components.
\end{abstract}

Aims: This study aims to compare cost recovery and financing systems of blood and blood products in different countries. Methods: This research was an email-based survey of 30 countries from four HDI categories. All related literature was reviewed.

Results: Out of 28 countries, 19 have blood and blood products that are provided totally free of charge to the patients. In nine countries blood and blood products are totally or partially chargeable to the patients.

Conclusions: In countries with low and lower-middle income economies, total or partial costs of blood and blood products are recovered directly from the patients. While countries in which blood and blood products are 'free of charge' for patients are mostly categorized in upper-middle- or high-income economies with well-developed healthcare and insurance systems. There is no clear relation between blood usage and the type of cost recovery system. However, having an efficient cost recovery system will help blood establishments to sustain their service delivery.

Keywords: blood, blood transfusion, rational blood use, cost recovery system, blood cost

Citation: Divkolaye NSH; Seighali F; Pourfathollah AA; Smit Sibinga CT. A country-wide comparison of cost recovery and financing systems of blood and blood products. East Mediterr Health J. 2019;25(2):104-110. https://doi.org/10.26719/emhj.18.020

Received: 08/02/17; accepted: 15/11/17

Copyright (c) World Health Organization (WHO) 2019. Some rights reserved. This work is available under the CC BY-NC-SA 3.0 IGO license (https:// creativecommons.org/licenses/by-nc-sa/3.0/igo).

\section{Introduction}

Blood transfusion as a life-saving treatment is an irrepressible part of modern healthcare. The World Health Organization (WHO) estimates that 112.5 million blood donations are collected across the world annually (1). However, data on the use of blood products is generally lacking, but studies suggest that blood components are often overprescribed in both high-income and low- and middle-income countries (2). It is estimated that worldwide over $50 \%$ of all medicinal interventions are prescribed, dispensed, or sold inappropriately (3).

Since blood is a scarce and expensive resource, irrational blood usage places huge burden on health expenditures (4). In a study conducted in the United States of America, the authors concluded that almost half of the transfusions were inadequately indicated causing an almost US\$ 860000 financial loss for a total of 10902 units (5).

However, the annual cost of providing blood and blood components is increasing (6). While blood donation is voluntary, the collection, processing, testing and distribution of blood and blood components incur significant costs. An American study published in April
2010 shows that the actual cost of blood is substantially higher than previously estimated. The study calculates that the true cost of blood for clinical use is 3.2 to 4.8 fold higher than reported blood component procurement costs. According to the study, when all the activities involved in blood transfusion are considered, the estimated price of transfusion of one unit of red cells is between US\$700-\$1200 (7). It is estimated that red blood cell transfusion costs at least US\$100 000000 yearly in Turkey (8). Comparing the cost related to the preparation of blood components, a much larger cost is incurred to run a blood establishment (9).

In addition, inappropriate use of blood and blood components may result in significant patient harm. An increasing number of studies show that there is a relationship between transfusion of blood components and the risk of morbidity and mortality (10-12). These adverse effects include allergic reactions, increased length of hospital stay, febrile nonhemolytic transfusion reaction, transfusion-related acute lung injury and circulatory overload in patients with heart disease. Although the existence of some confounding effects and lack of case-control studies make the causation difficult, the evidence alleging allogenic blood transfusion as the 
culprit for worsening patient outcomes continues to accumulate (13).

In response to this challenge and increasing demand for blood transfusion due to an escalating number of elective surgeries, advanced medical interventions and aging population specially in high-income countries (14), governments and healthcare providers are developing different strategies to rationalize blood utilization. These strategies range from patient blood management and using blood transfusion alternatives such as autologous blood procurement, erythropoiesis-stimulating agents, and haemostatic agents to improving blood inventory management system and enhancing awareness of unit prices (15). The idea of supporting a relation between underestimating the actual costs of blood and blood products and irrational blood usage has led some countries such as the Ilsamic Republic of Iran (16) and Australia (17) to review their current fully governmentfunded 'free of charge' policies and sending price signals to the prescribing clinicians as an incentive to take appropriate decision and bear the financial consequences.

A cost-recovery system named 'free of charge' means that the consumer and/or end-consumer are not charged for preparation and processing of blood and blood products. In this situation the government (tax money) finances $100 \%$ of blood transfusion service or the costs are recovered by the insurer fund or both (government and insurers). The system is named 'totally or partially chargeable to patients' when either the blood establishment or the hospital directly charge the endconsumer for the total or partial costs of blood or blood products. This study aimed to 1) compare cost recovery and financing systems in different countries for blood and blood products; and 2) find out whether the type of reimbursement system has any effect on rational use of blood. The emphasis is on the system in use and not on the calculation of the costs involved, and whether the system in use relates to the validity of clinical use of blood and blood products.

\section{Methods}

An email-based survey was sent to blood transfusion experts and executive authorities within different countries. Respondents were asked to answer questions regarding the cost recovery or reimbursement system of blood and blood products in their countries; the effects of the current system on the efficiency of blood usage; and the explanation of any other policies for reduction of blood wastage in their respective countries. A 5-question survey (Table 1) was sent by the Iranian Blood Transfu- sion Organization (IBTO) directorate. After one month, a reminder was sent out. Due to a lack of responses from certain countries, the data were derived from related literature, documents and websites. In addition, all other related literature and documents were reviewed. Statistical analysis was not needed for this descriptive comparative study.

\section{Results}

A total of 56 experts from 30 countries were contacted, and the experts of 17 countries (56\%) from Canada, Denmark, Finland, France, Germany, Hungary, India, Islamic Republic of Iran, Italy, Nepal, Netherlands, New Zealand, Nigeria, Pakistan, Slovakia, Turkey and United Kingdom completed the survey. The information of other countries (Australia, Bangladesh, Côte d'Ivoire, Mozambique, Namibia, Singapore, South Africa, Sri Lanka, Uganda, United States of America and Zimbabwe) surveyed in this study has been derived from available resources that were mentioned in the methodology.

In 19 out of 28 countries ( $67 \%$ ), blood and blood products are provided totally free of charge to the patients. In nine countries blood and blood components are chargeable to the patients but with some considerations; In India, it has been mandatory for all blood banks since 2012 to provide blood and blood products free of charge for the patients who require repeated blood transfusion as a life-saving intervention (18). In Pakistan and Sri Lanka there is no charge for blood and its products in governmental blood banks, if used inside governmental hospitals; however, patients are charged in private hospitals. In Nigeria, patients pay the equivalent of approximately US\$12 per unit of whole blood. In Mozambique, the expenses are recovered by direct charges to the patients and funding of foreign donors (19).

In other countries, the charges for whole blood range between US\$ 5 (Bangladesh) up to US\$ 43 (India when the blood is screened by Nucleic Acid Test (NAT) (20). In Singapore patients need to pay the blood processing fee, which is subsidized by the government (21). In the United States of America, the average charge to the hospitalized patient per red blood cell unit transfused was estimated US\$343.63 \pm 135 (22). There are two main sources of finance for the countries that provide blood and blood products free of charge to patients, namely government and insurers. In six out of 19 countries where blood and blood components are provided free to patients, the expenses are reimbursed to blood services directly by the government. In nine countries insurers pay the related costs and in four countries both government and insurers

\footnotetext{
Table 1 Questionnaire

Are blood and blood products provided free of charge to the patients?

How are the expenses reimbursed in your country; by government or insurers?

How much is the cost of whole blood, packed cells, platelets, fresh frozen plasma?

Have the current charging policies/reimbursment system been effective to rationalize blood usage?

What are other policies of your country to prevent wastage of blood?
} 
reimburse the expenses (Table 2).

Effective strategies to rationalize blood usage mentioned by the respondents are patient blood management; employing of transfusion medicine specialists; training programmes for physicians and nurses; integrated blood inventory management systems; developing guidelines for the appropriate clinical use of blood products and plasma-derived medicinal products; haemovigilance; and use of blood transfusion alternatives.

Out of six countries where the government reimburses the expenses, Australia and the Islamic Republic of Iran are not satisfied with this policy due to continued inappropriate blood usage by hospitals and are considering some revisions $(23,24)$. However, the experts of two other countries (Denmark and Italy) believe that applying a charging or cost-recovery policy is not effective on the awareness of rational blood usage. This information was not available for Canada and Uganda.

Of the two countries (France and UK) where both insurers and government reimburse the expenses, the respondents believe that there is not any relation between this policy and rational blood usage. In these countries, blood and its products are reimbursed by governments if they are distributed in governmental hospitals. There are also private hospitals treating patients covered by insurance policies and these hospitals will pass costs on to the insurers. Out of seven countries where insurers pay the related costs, the respondents from three countries (Germany, Finland and Hungary) believe that this policy has helped to rationalize blood usage and according to the replies received from another four countries

\begin{tabular}{|c|c|c|}
\hline Country (blood supply system)2 & Type of charging system for patients & $\begin{array}{c}\text { Type of cost recovery or financing } \\
\text { system }\end{array}$ \\
\hline \multicolumn{3}{|l|}{ Very High HDI3 } \\
\hline $\operatorname{USA}(\mathrm{H}, \mathrm{RC}, \mathrm{ABC})$ & Totally or partially chargeable & Insurers/patients \\
\hline UK $(\mathrm{N})$ & Free of charge & Government and insurers \\
\hline Netherlands (N) & Free of charge & Insurers \\
\hline France $(\mathrm{N})$ & Free of charge & Government/insurers \\
\hline Slovakia (N) & Free of charge & Insurers \\
\hline $\operatorname{Denmark}(\mathrm{H})$ & Free of charge & Government \\
\hline Hungary (N) & Free of charge & Insurers \\
\hline New Zealand (N) & Free of charge & Insurers \\
\hline Australia (RC) & Free of charge & Government \\
\hline Germany $(\mathrm{RC}, \mathrm{H})$ & Free of charge & Insurers \\
\hline Italy $(\mathrm{H})$ & Free of charge & Government \\
\hline Canada (RC, ABC) & Free of charge & Government \\
\hline Finland (RC) & Free of charge & Insurers \\
\hline Singapore (N) & Totally or partially chargeable & Government/patients/ insurers \\
\hline \multicolumn{3}{|l|}{ High HDI } \\
\hline Turkey (RC, H) & Free of charge & Insurers \\
\hline $\operatorname{Iran}(\mathrm{N})$ & Free of charge & Government \\
\hline Sri Lanka (N) & Totally or partially chargeable & Government/patients \\
\hline \multicolumn{3}{|l|}{ Medium HDI } \\
\hline South Africa (N) & Free of charge & Insurers \\
\hline Bangladesh $(\mathrm{H})$ & Totally or partially chargeable & Government/patients \\
\hline India $(\mathrm{H})$ & Totally or partially chargeable & Government/insurers/patients \\
\hline Namibia (N) & Free of Charge & Government/insurers \\
\hline \multicolumn{3}{|l|}{ Low HDI } \\
\hline Nepal (RC) & Totally or partially chargeable & Government/patients \\
\hline Pakistan (M) & Totally or partially chargeable & Government/patients \\
\hline Nigeria $(\mathrm{H})$ & Totally or partially chargeable & Government/patient \\
\hline Mozambique (M) & Totally or partially chargeable & Patients \\
\hline Côte d'Ivoire (N) & Free of charge & Government/ insures \\
\hline Zimbabwe (N) & Free of charge & Government/insurers \\
\hline Uganda (N) & Free of charge & Government \\
\hline
\end{tabular}


(Netherlands, New Zealand, Slovakia, Turkey,) this policy has a positive effect on awareness of rational blood usage.

\section{Discussion}

To cover the cost made by a blood establishment for the supply of blood and blood products to hospitals and the transfusion of blood at the bedside, there are several systems in operation in different parts of the world. Where a comprehensive healthcare system has been established, costs and cost recovery usually have been considered. In principle, the consumer pays for what has been consumed, whether materials or services or both (25). The end-consumer is the patient, although hospitals also may be considered as consumers. Costs made to provide agreed standards of care may be covered by tax revenue, by insurance funds or a combination (26).

In the absence of an accessible and affordable health insurance system, the end-consumer may be charged by the health provider for the cost of care including the service. Central to the system of provision of blood and blood products is the blood establishment or blood bank, which needs to recover the costs made to provide blood and blood products as well as the continuous supportive services (27). These costs may be recovered through the government, hospitals and or the insurance funds, but also directly by the end-consumer. Hospitals may recover the costs made for individual haemotherapy directly from the patient or indirectly from the insurance fund through which the patient is insured, or by the government (28). For example, in Côte d'Ivoire the government covers $73 \%$ of expenses while $15 \%$ of costs are reimbursed by public hospitals, 5\% from private hospitals and the remainder by miscellaneous sources such as charitable foundations (19).

According to WHO reports published in $2016,32 \%$ of countries had a specific item in their governmental budget for blood transfusion services; $16 \%$ had a cost recovery system; and 33\% reported having both a specific budget for blood services and a cost recovery system. The remaining $11 \%$ reported neither a specific budget nor a cost recovery system for blood transfusion services (29). According to the outcome of this survey, all countries where total or partial costs of blood and blood products are recovered directly from the patients are categorized as low and lower-middle income economies, which suffer from fragmented and non-centralized blood transfusion systems and an underdeveloped healthcare system. WHO's findings show that 24 countries continued to be dependent on paid donations in 2013, amounting to 1650000 donations in total (29). Since there is no united cost recovery system due to the absence of a structured healthcare system in these countries, the evaluation of the current policy on blood usage is not easy and in most cases there is neither a policy nor the necessary infrastructure in place to optimize blood usage. However, significant progress has been made in countries such as Côte d'Ivoire, India, Tanzania and Zimbabwe through centralization of blood establishments and development of national guidelines on clinical use of blood where blood and blood products are provided free of charge to the patients (except India) (19).

Generally, countries in which blood and blood products are 'free of charge' for patients are mostly categorized in upper-middle- or high-income economies with well-developed healthcare and insurance systems. Almost all of them benefit from a centralized, integrated and organized blood transfusion system where the government, insurers or both finance the related costs. Among WHO regions, European countries have the highest rate of reporting financing the blood services through a cost recovery (67\%), either partially or entirely (29).

As mentioned, irrational usage of blood and blood products in some countries where the government is the sole source of finance has led to a revision of current policy. These revisions are mainly focused on extending price signals in the system, particularly to hospitals (30). Since 2013, the Australian Red Cross Blood Service included a manufacturing cost indicator on all fresh blood products such as red blood cells, platelets and fresh (frozen) plasma. The aim of this national initiative is to increase the awareness and appreciation of the costs associated with the provision of blood and blood products within Australia (31). Suffering from the same challenge, since 2015 the Iranian Blood Transfusion Organization (IBTO) has adopted a new policy which was a shift from government as the sole funder of IBTO to the insurers as the partial funder of blood services. As a result, some of the blood products were incorporated into the pricing framework. It is planned to obtain $30 \%$ of the costs of IBTO's operations from this new cost recovery system. Given the fact that all Iranians are under the national insurance scheme, this new rule does not pose any significant financial burden on patients.

However, the existence of a possible relation between the type of reimbursement system and the amount of blood usage is disputed between the experts of the countries approached. Although experts of some countries with an advanced blood transfusion system such as France, Italy, Netherlands and the United Kingdom believe that rationalizing blood usage is usually more based on guidelines, training and education rather than implementing charging policies, the respondents from some countries where the insurers pay the related costs believe that this type of cost recovery system has a positive effect on rational use of blood.

Although the data from Red Blood Cells (RBC) consumption per 1000 population in different European Union (EU) countries and Australia, New Zealand and the United States of America in $2013(32,33)$ appear to support a relation between cost recovery system and blood usage, this relation is not conclusive. The data show that in countries with the lowest rate of $R B C$ consumption per 1000 population (Netherlands - 27, New Zealand - 26.6, and United States of America - 19.3), the costs are recovered by insurers and not government; the $\mathrm{RBC}$ usage is relatively high in countries which the government funds all blood transfusion activities 
(47 and 41.7 per 1000 population in Denmark and Italy respectively). Similarly this rate in France and the United Kingdom, with mix cost recovery systems (government and insurers), was reported to be 38.1 and 31.5 respectively (the median range). However, several exceptions apply to this observation; Australia (fully government-funded blood service) has low RBC consumption (29 per 1000 population). On the other hand, Germany, with insurerrecovered cost system, has one of the highest $\mathrm{RBC}$ usage rates among EU countries (54 per 1000 population). This indicates the importance of other factors intervening in the rational use of blood such as education, standards setting and guidelines, having an updated needs assessment system, and active collaboration between hospitals and blood services (clinical interface).

\section{Conclusion}

Apart from the effects on blood usage and cutting unnecessary costs, having an efficient cost recovery system will help blood establishments to sustain their service delivery and to ensure reliable revenue. This gains importance especially in countries with scarce resources where the existing funding (government or external donors) are generally insufficient to meet the demands for safe blood. For example, the Netherlands (population of approximately 17 million) has a successful cost recovery system where the Sanquin Blood Bank invoices the hospitals. The hospitals then invoice the insurance companies and the latter collect the annual insurance fee from either the individual or the employer, which compensates the health insurer through their monthly salary structure. Applying this policy not only has led to the recovery of related costs but also operate with a blood supply turnover of approximately €144 million in 2013 (34).

\section{Limitations}

Although this study is unique, the authors are aware of certain limitations. The study is based on a simple questionnaire and does not provide the detailed analysis of cost calculation. The approach has been descriptive rather than analytic when comparing the cost recovery/ reimbursement systems currently in practice and their assumed effect on clinical use of blood and blood components. However, due to the lack of information, some parts of the study are based on the views expressed by the blood transfusion authorities and experts from different countries. There is a need to conduct a more evidence-based and extensive research to verify and generalize the results.

\section{Acknowledgments}

We sincerely thank the following experts for their contribution: Dr. Toyin Smith, Nigeria; Dr Nuri Solaz, Turkey; Prof. Hassan Abbas Zaheer, Pakistan; Dr. Jana Rosochova, Slovakia; Dr Pierre-François Falcou, France; Prof. Rainer Seitz, Germany; Mr. Jasper Villumsen, Denmark; Dr Manita Rajkarnikar, Nepal; Dr. Giuliano Grazzini, Italy; Ms. Teresa Allen, United Kingdom; Dr Klara Baroti-Toth, Hungary; Prof Graeme Woodfield, New Zealand; Dr Nabajyoti Choundhury, India; Prof Tom Krusius, Finland; Dr Gilles Follea, European Blood Alliance; and Dr Sima Zolfaghari, Islamic Republic of Iran.

Funding: None.

Competing interests: None declared.

\section{Comparaison des systèmes de financement et de recouvrement des coûts pour le sang et les produits sanguins dans différents pays}

\section{Résumé}

Contexte : Le sang étant une ressource rare et coûteuse, son utilisation irrationnelle pèse très lourd sur les dépenses de santé. En réponse à ce problème, les gouvernements et les prestataires de soins de santé développent différentes stratégies visant à optimiser l'utilisation du sang. L'une d'elle consiste à essayer de sensibiliser le public aux coûts réels de la production de sang et de modifier les systèmes de recouvrement des coûts associés au sang et à ses composants.

Objectifs : La présente étude a pour but de comparer les systèmes de financement et de recouvrement des coûts pour le sang et les produits sanguins dans différents pays.

Méthodes : Ces travaux de recherche consistaient en une enquête réalisée par courriel et menée dans 30 pays répondant à quatre catégories d'indice de développement humain. Toute la littérature connexe a été passée en revue.

Résultats : Sur 28 pays, 19 fournissent gratuitement aux patients le sang et les produits sanguins. Ils sont en revanche totalement ou partiellement à la charge des patients dans neuf pays.

Conclusions : Dans les pays à revenu faible ou intermédiaire de la tranche inférieure, les coûts associés au sang et aux produits sanguins sont recouvrés, pour tout ou partie, directement auprès des patients. En revanche, la plupart des pays où le sang et les produits sanguins sont «gratuits» pour les patients figurent parmi ceux dont le revenu est élevé ou intermédiaire supérieur et qui sont dotés de systèmes de santé et d'assurance bien développés. Aucune relation claire entre l'utilisation du sang et le type de système de recouvrement des coûts n'a été identifiée. Toutefois, l'existence d'un système de recouvrement des coûts efficace aidera les établissements du sang à maintenir leurs prestations de services. 


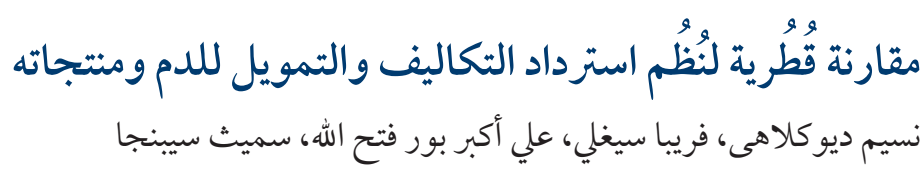

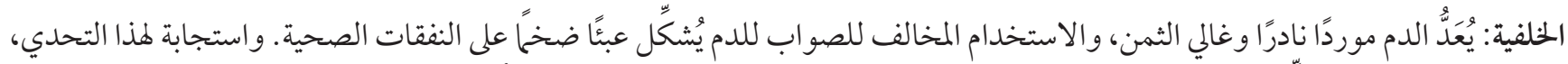

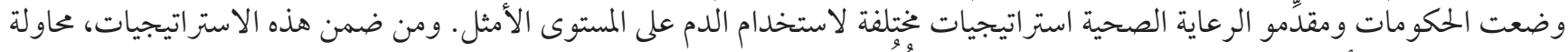

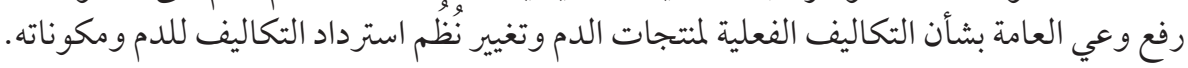
الأهداف: هدفت هذه الدراسة إلى مقارنة نظّم استرداد التكاليف و التمويل للدم ومنتجاته في البلدان المختلفة.

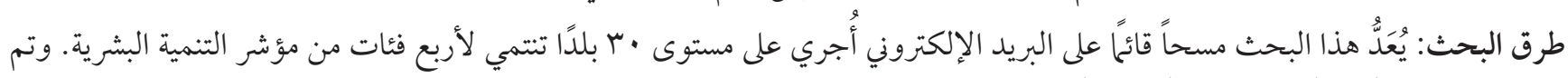

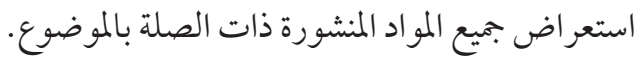

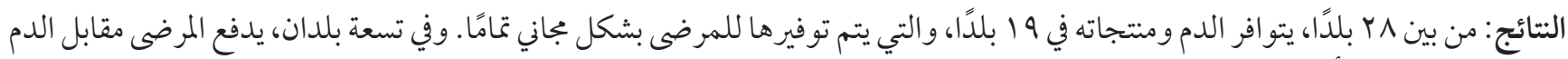
ومنتجاته بشكل كلي أو جزئي.

الاستنتاجات: في البلدان ذات اقتصاديات الدخل المنخفض و المتوسط الأدنى، يتم استرداد تكاليف الدم ومنتجاته كليًا أو جزئيًا من المرضى مباشرةً.

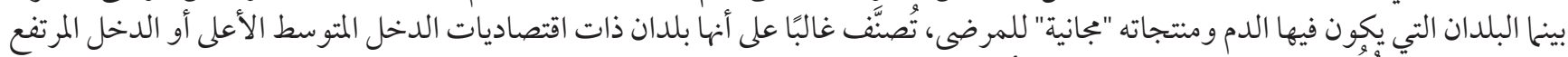

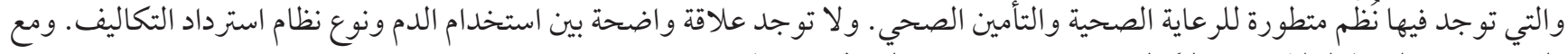

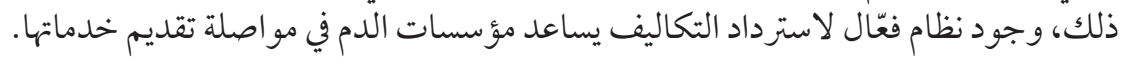

\section{References}

1. Blood safety and availability. Fact sheet N²79. Geneva: World Health Organization; 2014 (http://www.who.int/mediacentre/factsheets/fs279/en, accessed 3.04.17) 2014 .

2. Blood transfusion safety. Safe and rational clinical use of blood. Geneva: World Health Organization; 2016. (http://www.who.int/ bloodsafety/clinical_use/en/, accessed 3 April 2016)

3. Promoting Rational Drug Use under NRHM. Geneva: World Health Organization; 2002 (http://fkilp.iimb.ernet.in/pdf/Healthcare_Quality/Quality_Initiatives_National_Regional_\&_Local\%2oLevels/NRHM_WHO_Promoting_rational_drug_use_under_ NRHM.pdf; accessed 13.05.15).

4. Shander A, Hofmann A, Gombotz H, Theusinger OM, Spahn DR. Estimating the cost of blood: past, present, and future directions. Best Pract Res Clin Anaesthesiol. 2007;21(2):271-89. http://dx.doi.org/10.1016/j.bpa.2007.01.002

5. Cázares-Benito MA, Cázares-Tamez A, Pérez-Chávez F, Díaz-Olachea CG, Ramos-García AG, Díaz-Chuc EA, et al. Impact on costs related to inadequate indication of blood transfusion. Medicina Universitaria. 2016;18(72):148-52. http://dx.doi.org/10.1016/j. rmu.2016.07.003

6. Toner RW, Pizzi L, Leas B, Ballas SK, Quigley A, Goldfarb NI. Costs to hospitals of acquiring and processing blood in the US: a survey of hospital-based blood banks and transfusion services. Appl Health Econ Health Policy. 2011;9(1):29-37. http://dx.doi. org/10.2165/11530740-000000000-00000

7. Shander A, Hofmann A, Ozawa S, Theusinger OM, Gombotz H, Spahn DR. Activity-based costs of blood transfusions in surgical patients at four hospitals. Transfusion. 2010;50(4):753-65. http://dx.doi.org/10.1111/j.1537-2995.2009.02518.x

8. Oge T, Kilic CH, Kilic GS. Economic Impact of Blood Transfusions: Balancing Cost and Benefits. The Eurasian Journal of Medicine. 2014;46(1):47-9. http://dx.doi.org/10.5152/eajm.2014.08

9. Shander A. The cost of blood: multidisciplinary consensus conference for a standard methodology transfusion. Transfus Med Rev. 2005;19(1):66-78. http://dx.doi.org/10.1016/j.tmrv.2004.09.005

10. Chatterjee S, Wetterslev J, Sharma A, Lichstein E, Mukherjee D. Association of blood transfusion with increased mortality in myocardial infarction: a meta-analysis and diversity-adjusted study sequential analysis. JAMA Intern Med. 2013;173:132-39.

11. Musallam KM, Tamim HM, Richards T, Spahn DR, et al. Preoperative anaemia and postoperative outcomes in non-cardiac surgery: a retrospective cohort study. Lancet 2011;378: 1396-407.

12. Al-Refaie WB, Parsons HM, Markin A, Abrams J, Habermann EB. Blood transfusion and cancer surgery outcomes: a continued reason for concern. Surgery. 2012 Sep;152(3):344-54.

13. Shander A, Goodnough LT. Can blood transfusion be not only ineffective, but also injurious?. Ann Thorac Surg. 2014 ;97:11-14.

14. Ali A, Auvinen MK, Rautonen J. The aging population poses a global challenge for blood services. Transfusion. 2010;50:584-88.

15. Spahn DR, Goodnough LT. Alternatives to blood transfusion. Lancet. 2013 ;381:1855-65.

16. Incorporating tariffs to 14 services of blood transfusion. 5 March 2017. (http://www.irna.ir/fa/News/82452407//). 
17. Australian Red Cross Blood Service Submission to the Independent Hospital Pricing Authority. (http://www.ihpa.gov.au/internet/ ihpa/publishing.nsf/AttachmentsByTitle/submissions/\$FILE/Australian+Red+Cross+Blood+Service.pdf).

18. Guideline for recovery of processing charges for blood and blood components, Government of India, Ministry of Health; 2014 (http://naco.gov.in/upload/Blood\%20Saftey/guidelines.pdf).

19. Hensher M, Jefferys E. Financing blood transfusion services in sub-Saharan Africa: a role for user fees?. Health Policy Plan. 2000 Sep;15(3):287-95.

20. Choudhury N. Prices of blood units in South East Asia. Asian J Transfus Sci. 2008;2:45-46.

21. Blood Transfusion. Health Sciences Authority of Singapore. (http://www.hsa.gov.sg/content/hsa/en/Blood_Services/Transfusion_Medicine/Blood_Transfusion.html).

22. Toner RW, Pizzi L, Leas B, Ballas SK, Quigley A, Goldfarb NI. Costs to hospitals of acquiring and processing blood in the US: a survey of hospital-based blood banks and transfusion services.Appl Health Econ Health Policy. 2011;9:29-37

23. Pourfathollah AA, Hosseini Divkolaye NS, Seighali F. Four decades of National Blood Service in Iran: outreach, prospect and challenges. Transfus Med. 2015 ;25:138-43

24. Options to Manage Appropriate Use of Blood and Blood Products;2011 (https://www.health.gov.au/internet/main/publishing.nsf/ Content/foi-disc-log-2012-13/\$File/APPROPRIATE\%20USE\%20FINAL\%2030\%20August\%2011.pdf).

25. Thomson S, Foubister T.Financing Health Care in the European Union. Challenges and Policy Response. Copehagen: WHO Regional Office for Europe; 2009.

26. Costing Blood Transfusion Services. WHO/BLS/98.8. Geneva: World Health Organization; 1998.

27. Paolucci F. Health Care Financing and Insurance. Options for Design. Berlin: Springer; 2010.

28. Mingshan L, Johnson E. Financing Health Care. New ideas for a changing society. Wiley-VCH Verlag GmbH; 2007.

29. Global Status Report on Blood Safety and Availability. Geneva: World Health Organization; 2016(http://apps.who.int/iris/bitstrea m/10665/254987/1/9789241565431-eng.pdf).

30. Analysis of Cost Drivers and Trends in the Blood Sector. Department of Health and Ageing. Australian government; 2014 (http:// www.health.gov.au/internet/main/publishing.nsf/Content/foi-disc-log-2011-12/\$File/FOI\%20158-1112\%20document\%201.pdf).

31. Manufacturing costs on all blood component labels. National Blood Authority Australia. (http://www.blood.gov.au/manufacturing-costs-all-blood-component-labels).

32. van Hoeven LR, Janssen MP, G Rautmann G. The collection, testing and use of blood and blood components in Europe. European Directorate for the Quality of Medicines \& HealthCare, Council of Europe; 2013 (https://www.edqm.eu/sites/default/files/the_collection_testing_and_use_of_blood_and_blood_components_in_europe_2012_report.pdf).

33. The AABB Blood Survey Report; 2013 (http://www.aabb.org/research/hemovigilance/bloodsurvey/Documents/2013-AABB-Blood-Survey-Report.pdf).

34. Notes to profit and loss account. Annual Report 2013. Sanquine Blood Supply. (http://2013.annualreportsanquin.nl/annual-report-2013/a1028_Notes-to-the-profit-and-loss-account). 